\title{
Financial Soundness Indicators in Nigeria: Does Economic Condition Matters?
}

\author{
Bello Yakubu A. \\ Statistics Department, Central Bank of Nigeria \\ Salihu Audu \\ Statistics Department, Central Bank of Nigeria \\ Baba N. Yaaba \\ Statistics Department, Central Bank of Nigeria \\ Ibrahim Hamman \\ Statistics Department, Central Bank of Nigeria \\ Gambo Ali Idrisa \\ Statistics Department, Central Bank of Nigeria \\ Usman Farida B. \\ Statistics Department, Central Bank of Nigeria
}

\begin{abstract}
The growing concern amongst analysts, economists, and policy makers on the interrelationship between the soundness of the financial system and the macroeconomy is gradually being confirmed by both theoretical and empirical studies. This study is an attempt to join the strand of literature that investigates the link between the soundness of the banking sector and macroeconomic performance using Nigeria's quarterly data from 2007Q1 to 2018Q4. The study applied autoregressive distributed lag approach and found among others that FSIs are strongly related to macroeconomic variables, hence capable of pre-empting financial crisis in Nigeria. The study, therefore, recommends that movements in macroeconomic variables should be used by the Central Bank of Nigeria to take proactive supervisory policy measures to avert a systemic crisis in the banking sector.
\end{abstract}

Key Words: FSIs, Banking sector, financial crisis, ARDL

JEL Classification: E44, G21, G28

\section{INTRODUCTION}

The occurrence and reoccurrence of financial crisis, despite various regulatory efforts by national and multilateral agencies such as the International Monetary Funds (IMF), Bank for International Settlement (BIS), among others, have become a matter of concern not only to the national regulators and market players but also to market participants, financial analysts and academic researchers. While some are of the view that financial crises are induced by the reckless activities of the managers', particularly their penchant for excessive risks, abnormal profit and robust reward packages, others argue that the regulators are most culpable, considering their preference for micro-prudential regulation even at a time when macroprudential regulatory framework is the most potent option. More still, others tend to look beyond these two reasons by attributing the financial crisis also, to harsh macroeconomic conditions such as sluggish economic activities and unstable general price levels (Claessens \& Kodres, 2014). 
The aftermath of the Asian financial crisis of 1997/98 saw the birth of Financial Soundness Indicators (FSIs) by the International Monetary Fund (IMF). The Fund, in conjunction with the international financial community, conceived the idea of some statistical initiatives to enhance the coverage of potential financial and external vulnerabilities in the system. Prominent among the initiatives are: financial soundness indicators (FSIs); international reserves and foreign currency liquidity template; and external debt statistics. The FSIs measure the financial health and soundness of the financial institutions in a country as well as their corporate and household counterparties (IMF, 2006). The need for the compilation of the FSIs was however not strengthened until the emergence of the Global Financial Crisis (GFC), which started from the subprime mortgage sector of the United States in 2008/09. The Statistics Department of the Central Bank of Nigeria started the compilation of quarterly FSIs in 2010 but worked it back to 2007 .

Although several studies have been conducted to determine the cause of the soundness and/or vulnerabilities of the Nigerian financial system ${ }^{1}$, they largely used soundness indicators compiled in line with CAMEL ratings. This study is an attempt to assess the relationship between Nigeria's macroeconomic fundamentals and the FSIs compiled in line with the IMFFSIs Guideline. This will help policymakers in Nigeria understand the validity of the argument on the major determinants of the health of the Nigerian banking system. In other words, the study is an attempt to confirm or refute the argument that the soundness of the financial system is a function of either macroeconomic fundamental (i.e. the level of economic activities proxy by GDP, Inflation, exchange rate), or ability or otherwise of the regulatory authorities to efficiently enforce prudential requirements and/or the excesses of banks managers.

To achieve this objective, the study is divided into five sections. Following this brief introduction is section two, which highlight the theoretical foundation of linkages between macroeconomic fundamentals and the financial system. The section also discusses the trend of the size and performance of the Nigerian banking system as well as review related empirical literature. Section three presents the methodology while four discusses the results and section five gives the conclusion and proffer some policy recommendations.

\section{THEORETICAL FOUNDATION AND EMPIRICAL LITERATURE}

\section{Macro-Financial Linkages}

"Macro-financial linkages" can be viewed from different perspectives. While some analysts see it as the interaction between the domestic economic fundamentals and the financial system, others are of the view that, it can also be referred to as the interactions among the domestic economy and international financial flows or the linkages from the domestic financial system to the rest of the world ${ }^{2}$. This paper recognizes all the perspectives but considers only the domestic linkages with emphasis on the interaction between the domestic financial system and the real economy, and running from macro-fundamentals to the financial system, taking cognizance of regulatory and supervisory efforts of the regulatory institutions.

There is divergence of opinion among economists, analysts, and even players and participants in the financial market as to whether health and soundness of the financial system stems from the developments in the macro-economy or changes in the macro-economy is usually induced by the developments in the financial system. Proponents of the former, which is the concern of this paper, argue that the connection is a one-way traffic running from the macro-economy to the financial system, such that developments in the real economy largely determines what

${ }^{1}$ See Yaaba (2011), Yaaba and Adamu (2015) and Yaaba (2016)

${ }^{2}$ Caprio (2011) 
happens in the financial system. They cited the case of an economic recession that is mostly accompanied by a fall in the stock market, and that the reverse does not always hold ${ }^{3}$. Predating the Samuelson submission is the Modigliani-Miller (1958) theorem which states that capital investment through debt and equity does impact on the value of the firm. A firm's investment decision, particularly on expansion through new acquisition of capital, is largely dictated by macroeconomic conditions such as the real interest rate which in turn is a function of marginal product of capital or the consequence of monetary policy stance at least in the short-run, but not, in any case, a fall out of the developments in the financial system. To the proponents of this view, the financial system does not influence the real economy (Morley, 2015) or has too little influence on the real economy ${ }^{4}$.

Table 1: Size of the Nigerian Banking System in Trillion Naira

\begin{tabular}{crrrr}
\hline \hline Period & $\begin{array}{c}\text { Commercial } \\
\text { Banks }\end{array}$ & $\begin{array}{c}\text { Merchant } \\
\text { Banks }\end{array}$ & $\begin{array}{c}\text { Non-Interest } \\
\text { Bank }\end{array}$ & Total \\
\hline \hline 2013Q1 & 22.30 & 0.03 & 0.01 & 22.34 \\
2013Q2 & 22.52 & 0.11 & 0.01 & 22.64 \\
2013Q3 & 23.28 & 0.13 & 0.01 & 23.42 \\
2013Q4 & 24.30 & 0.13 & 0.02 & 24.45 \\
2014Q1 & 24.57 & 0.15 & 0.04 & 24.76 \\
2014Q2 & 25.11 & 0.11 & 0.04 & 25.25 \\
2014Q3 & 25.95 & 0.12 & 0.04 & 26.12 \\
2014Q4 & 27.48 & 0.16 & 0.04 & 27.69 \\
2015Q1 & 28.66 & 0.19 & 0.05 & 28.90 \\
2015Q2 & 28.35 & 0.16 & 0.05 & 28.56 \\
2015Q3 & 28.11 & 0.19 & 0.05 & 28.36 \\
2015Q4 & 28.12 & 0.20 & 0.06 & 28.37 \\
2016Q1 & 28.51 & 0.40 & 0.06 & 28.97 \\
2016Q2 & 31.23 & 0.43 & 0.07 & 31.73 \\
2016Q3 & 31.72 & 0.45 & 0.07 & 32.24 \\
2016Q4 & 31.61 & 0.45 & 0.07 & 32.13 \\
2017Q1 & 32.35 & 0.45 & 0.08 & 32.88 \\
2017Q2 & 32.79 & 0.50 & 0.09 & 33.37 \\
2017Q3 & 33.22 & 0.54 & 0.09 & 33.85 \\
2017Q4 & 34.50 & 0.55 & 0.09 & 35.15 \\
2018Q1 & 35.58 & 0.62 & 0.10 & 36.30 \\
2018Q2 & 35.52 & 0.66 & 0.10 & 36.29 \\
2018Q3 & 37.16 & 0.69 & 0.10 & 37.96 \\
2018Q4 & 37.09 & 0.69 & 0.11 & 37.89 \\
\hline
\end{tabular}

\section{The Size and Strength of the Nigerian Banking System}

The Nigerian banking landscape over time has been dominated by commercial banking. Table 1 shows the size of the Nigerian banking sector in terms of assets. A cursory examination of the

\footnotetext{
3 This is contained in the Newsweek article of Paul Samuelson in 1966 titled: Wall Street Indexes Predicted Nine out of the Last Five Recessions".

4 The concept of 'financial accelerator' as well as the Global Financial Crisis (GFC) of 2007/08 that emanated from the mortgage sector of United States, however proved this assertion wrong. We will however not dwell much on it considering that our interest lies on link running from macro-Fundamentals to the Financial system.
} 
table indicates that assets of commercial banks (CBs) as at 2013Q1 stood at $\$ 22.30$ Trillion, and grew to $\$ 37.09$ Trillion by 2018Q4. While those of merchant banks (MBs) and non-interest banks (NIBs) grew from $\$ 0.03$ Trillion to $\$ 0.69$ Trillion and $\$ 0.01$ trillion to $\$ 0.11$ Trillion, respectively. As at 2018Q4, the asset base of CBs stood at 97.89 percent of the total assets of other depository corporations (ODCs).

Figure 1 presents selected financial soundness Indicators - capital adequacy ratio (CAR), Tier1 capital to risk-weighted assets (RWA), return on assets (ROA) and ratio of non-performing loans to total liability (NPL/TL) for the Banking system from 2007Q1 to 2018Q4. The indicators reported a mixture of stability and fragility during the study period. Considering regulatory capital to risk-weighted assets (CAR), for instance, it was 19.3 percent in $2007 \mathrm{Q} 1$ which was far above the international convention of 8.0 percent and the national minimum standard of 10.0 percent. The system maintained the strength until 2009Q4 when the CAR fell to as low as 4.1 percent in the wake of the global financial crisis. This trend continued until it reached the bottom low of 0.2 percent in 2010Q3. However, due to the intervention of the CBN, the CAR recovered to 1.8 percent in 2010Q4 and continued until it reached 19.6 percent in 2013Q1 when it began to decline again. The CAR was 11.5 percent at the end of the second quarter of 2017 and 15.2 percent in 2018Q4.

In the same vein, nonperforming loans/total loan (NPL/TL) was on the downward trend until the impact of the GFC on the Nigerian economy in 2009Q15. The upsurge in NPL/TL continued until it peaked at 38.3 percent in $2010 \mathrm{Q} 2$ and began to decline, due to the CBN interventions, which includes the six hundred and twenty billion Naira ( $\$ 620.0$ billion) injection into some troubled banks in form of Tier 2 capital, as well as some other quantitative easing measures (Abubakar and Yaaba, 2013). The NPL as a ratio of TL became single digit (9.9 percent) in 2011Q3 and remained so until 2016Q2 when it rose to 10.7 percent and further deteriorated to 15.0 percent in 2017Q2 and has since been improving until it reached 11.7 percent in 2018Q4. The recent downturn in the NPL/TL is attributable to the recent intervention of AMCON in buying up the toxic assets of the banking system.

${ }^{5}$ See Yaaba and Adamu (2015), Sere-Ejembi et al, (2014) and Yaaba (2013). 
Figure 1: Selected Financial Soundness Indicators for Nigeria, 2007Q1 to 2018Q4

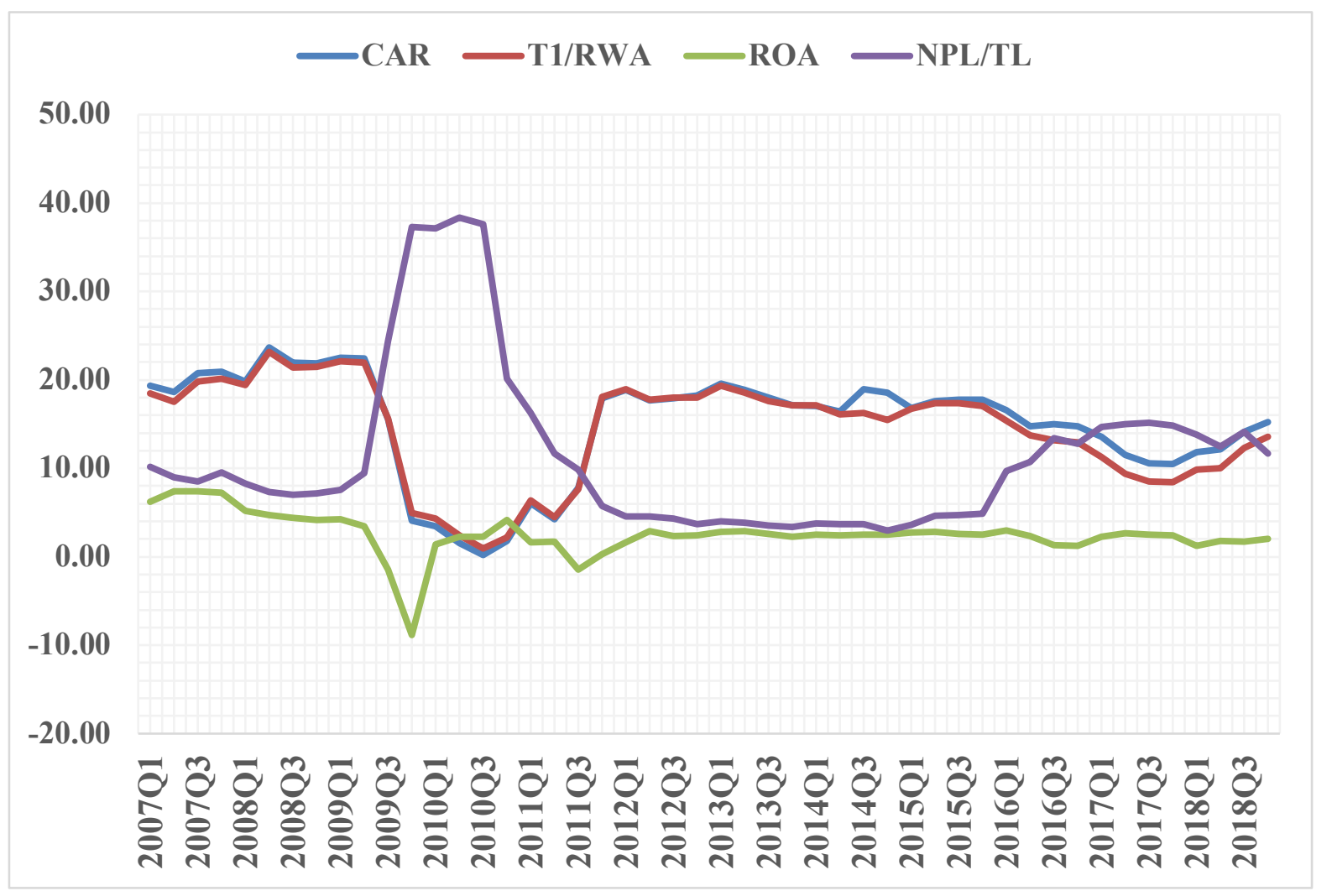

\section{Review of Empirical Literature}

Numerous literature abounds on the relationship between macroeconomic fundamentals and soundness or fragility of the financial system. There is a large strand of literature that supports the positive impact of sound macroeconomic variables on the health of the financial system particularly the banking sector. Some researchers argue in favour of a strong link between macroeconomics and financial soundness indicators, based on the Schumpeterian proposition that financial system serves as bedrock to economic development. However, others are of the view that the reverse is the case implying that robust economic performance leads to a sound financial system.

For instance, Demirgüç-Kunt and Detragiache (1998) examined the determinants of banking crises in developing and developed countries using a multivariate logit model. The study analyzed the macroeconomic indicators that are associated with the emergence of banking crises covering the period 1980 - 1994. The authors observed that crises tend to occur in an environment of low growth, high inflation, and high real interest rates as well as countries with explicit deposit insurance schemes.

Das, Quintyn, and Chenard (2004) applied the multivariate cross-sectional technique to model the impact of regulatory requirements on financial system stability in advanced, transition and developing economies. They adopted three sets of control variables to account for the macroeconomic impact, the structure of the financial system, the broader institutional, and governance environment. They found that regulatory requirements and low fiscal deficit are constituents of the determinants of banking system stability. 
Shahbaz, Shamim, and Aamir (2010) examined the impact of the macroeconomic environment on the performance of the Pakistan financial sector. They applied a fully modified ordinary least square (FMOLS) and error correction model (ECM) on Pakistan data. The result of the study revealed that government policies on financial institutions, foreign remittances, trade openness and economic growth were instrumental to the performance of the financial system in Pakistan, while inflation, literacy rate and political instability negatively affect the financial system.

Dhal, Kumar, and Ansari (2011) studied issues relating to the linkages of financial stability with economic growth and inflation in the Indian perspective using quarterly CAMEL indicators covering thirty-nine variables from 1997 - 2012. The authors used vector auto-regression (VAR) model covering output, inflation, interest rates and a banking sector stability index for the analysis. The result revealed that financial stability and macroeconomic indicators share a statistically significant bi-directional causal relationship. Also, the impulse response function of the VAR model provides some interesting perspectives. Firstly, financial stability, growth and inflation could share a medium-longer-term relationship and financial stability could be associated with higher growth accompanied by softer interest rates and without threat to price stability in the medium to long term. Also, they found out that with financial stability, output growth could become persistent and inflation less persistent

Jahn and Kick (2012) used a difference generalized method of moments (GMM), stimulation and standard fixed-effects model including the lagged dependent variable as an additional regressor to examine the determinants of banking system stability in Germany. The study utilized panel data across a large set of banks over the period 1995 to 2010. They found that many macro-prudential indicators such as asset price indicators, leading indicators for the business cycle and money market indicators as well as regional spillovers were essential determinants of banking system stability.

Similarly, Creel, Hubert and Labondance (2014) applied panel GMM with instrumental variables on European Union (EU) annual data from 1998 to 2011 based on the standard relationship framework established by Beck and Levine (2004) to assess the link between financial soundness and economic fundamentals in the EU. The authors estimated the causal relationship between the two variables while controlling for the financial depth of the economy, and found that there exists a negative impact of financial instability on economic growth in the region.

Albulescu (2014) used a panel data approach to test the influence of financial soundness indicators on banks' profitability at the macro-level of some emerging countries and discovered that non-performing loans had a negative impact on banks' profitability under the fixed effect model. However, the level of liquidity had mixed influence, while capitalization and interest rate margins positively affected banks' profitability.

Petria, Capraru and Ihnatov (2015) investigated the determinants of banks' profitability in 27 EU banking sector and found that credit and liquidity risk, management efficiency, diversification of business, market concentration/competition and economic growth influence bank profitability. In an empirical investigation of the dynamic linkages between FSIs and macroeconomic variables using ARDL approach, Yaaba (2016) used Nigerian data covering the period 2007 to 2015 and found that macroeconomic variables dictate the state of health of the Nigeria financial system. The author observed that the level of economic activities (real GDP) negatively affects capital adequacy but positively influences asset quality and banks' 
profitability. Also as inflation rises, asset quality deteriorates, banks profitability diminishes and asset quality wanes as the local currency depreciates.

\section{METHODOLOGY AND ESTIMATION PROCEDURE}

The data for the study is sourced from the Statistical bulletin of the Central Bank of Nigeria, the Electronic and Financial System Surveillance (eFASS) and Financial Analysis (Fina) which are applications used by the Deposit Money Banks (DMBs) to submit data to the Central Bank of Nigeria as well as the database of the Statistics Department of the CBN6. The data spans through the first quarter of 2007 to the fourth quarter of 2008. The study utilizes the autoregressive distributed lag (ARDL) approach to assess the dynamic linkages between the indicators of financial soundness on one hand and macroeconomic-fundamentals on the other. The advantage of ARDL over all other methodologies stemmed from its ability to accommodate variables either at level or first difference or both. The methodology is also inclined to small data size, hence can yield high standard results irrespective of the data length (Pesaran Shin and Smith, 2001; Harris \& Sollis, 2003).

Following Yaaba (2016), and in line Babihuga (2007), the study considers two models, capital adequacy indicator model and asset quality indicator model to capture the different dimensions of financial soundness. For a central bank, for instance, bank soundness can be interpreted to imply satisfaction of the regulatory requirements and/or ability to intermediate, while for depositors, banking soundness implies liquidity and it means profitability to the shareholders, thus modeling the linkages among economic conditions and banks soundness requires wide-ranging approaches.

The capital adequacy based model takes the form:

$$
\operatorname{car}_{t}=\theta+\gamma c a r_{t-1}+\delta y_{t}+\omega \pi_{t}+\xi m p r_{t}+\lambda e x r_{t}+\eta \operatorname{lsi}_{t}+\beta m s_{t}
$$

The Asset Quality is modeled as:

$$
a q_{t}=\alpha+\gamma a q_{t-1}+\delta y_{t}+\omega \pi_{t}+\xi m p r_{t}+\lambda e x r_{t}+\eta a s i_{t}
$$

Where car stands for capital adequacy ratio, $y$ is the level of economic activities proxy by gross domestic product (gdp), $\pi$ stands for inflation, $m p r$ is the monetary policy rate, exr is the bilateral exchange rate between the Naira and US Dollar, asi represents all share index, $m s$ stands for the oligopolistic structure of the market, derived as total deposit of five banks with the highest deposits to the total deposit liabilities of banks. In other words, it is derived as the deposit share of 20 percent of banks that holds about 51.4 percent of the sector deposits. Aq denotes assets quality, $\theta$ and $\alpha$ are constants, whereas $\gamma, \delta, \omega, \xi, \lambda, \eta$ and $\beta$ are the coefficients of the respective variables.

Following Pesaran, Shin and Smith (2001) the ARDL formats of equations 1 and 2 are presented as:

$$
\Delta l c a r_{t}=\theta+\sum_{i=1}^{m} \gamma_{i} \Delta l c a r_{t-i}+\sum_{i=0}^{n} \delta_{i} \Delta l x_{t-i}+\varpi_{1} l c a_{t-1}+\varpi_{2} l x_{t-1}+\mu_{t}
$$




$$
\Delta l a q_{t}=\theta+\sum_{i=1}^{m} \gamma_{i} \Delta l a q_{t-i}+\sum_{i=0}^{n} \delta_{i} \Delta l x_{t-i}+\varpi_{1} l a q_{t-1}+\varpi_{2} l x_{t-1}+\mu_{t}
$$

Where $x$ is a vector of explanatory variables as presented in equations (1) and (2), $\Delta$ is a difference operator, $l$ represents natural logarithm, $m$ and $n$ are lag lengths and $\mu$ is error term. All other variables are as defined under equations 1 and 2 .

The error correction representations of equations 1 and 2 take the form of:

$$
\begin{aligned}
& \Delta l \operatorname{lcar}_{t}=\theta+\sum_{i=1}^{m} \gamma_{i} \Delta \operatorname{lcar}_{t-i}+\sum_{i=0}^{n} \delta_{i} \Delta l x_{t-i}+\Omega e c m_{t-1} \\
& \Delta l a q_{t}=\theta+\sum_{i=1}^{m} \gamma_{i} \Delta l a q_{t-i}+\sum_{i=0}^{n} \delta_{i} \Delta l x_{t-i}+\Omega e c m_{t-1}
\end{aligned}
$$

Where ecm is the error correction term and $\Omega$ represents the speed of adjustment.

Two stages are involved in the estimation of equation 3 and 4 . We first define the null hypothesis of the non-existence of the long-run relationship among the variables as: $H_{0}$ : $\varpi_{1}=$ $\varpi_{2}=0$. The null is then tested against the alternative of $\mathrm{H}_{1}$ not $\mathrm{H}_{0}$ by conducting the Wald test. The existence of a long-run relationship among the variables is confirmed by the rejection of the null hypothesis. If the calculated F-statistics is above the upper critical value bounds as tabulated in Pesaran, Shin and Smith (2001), the null hypothesis is rejected thereby indicating Cointegration, If the calculated F-statistics fall below the lower critical value bounds, the null cannot be rejected and if the F-statistics lies in between the two bounds, the result can be said to be inconclusive.

\section{Time series properties of the data}

\section{DISCUSSION OF EMPIRICAL RESULTS}

\section{Summary Statistics}

The descriptive statistics as presented in Table 2 reveals that the minimum observation for log of capital adequacy ratio is -1.62 while the maximum stands at 3.16 . The variables (lcar) recorded 2.51 and 2.84 as the mean and median, respectively and the skewness of -2.91 indicates that the data is negatively skewed. In the same vein, lry and Impr recorded means and medians of 9.60 and 2.36; and 9.65 and 2.48, respectively. The kurtosis of the distribution ranges between 1.97 and 12.51 implying the distribution is asymmetric (Table 2). 
Table 2. Summary Statistics

\begin{tabular}{lllllllll}
\hline \hline & Icar & laq & Iry & Icpi & Impr & lexr & lasi & Ims \\
\hline \hline Mean & 2.51 & 2.18 & 9.60 & 4.95 & 2.36 & 5.17 & 10.36 & 3.98 \\
Median & 2.84 & 2.22 & 9.65 & 4.96 & 2.48 & 5.06 & 10.36 & 3.97 \\
Maximum & 3.16 & 3.65 & 9.85 & 5.62 & 2.64 & 5.73 & 11.05 & 4.01 \\
Minimum & -1.62 & 1.09 & 9.26 & 4.31 & 1.79 & 4.77 & 9.90 & 3.95 \\
Std. Dev. & 0.87 & 0.71 & 0.17 & 0.38 & 0.27 & 0.31 & 0.30 & 0.02 \\
Skewness & -2.91 & 0.37 & -0.45 & 0.05 & -0.91 & 0.84 & 0.38 & 0.99 \\
Kurtosis & 12.51 & 2.37 & 2.05 & 1.97 & 2.63 & 2.42 & 2.42 & 2.81 \\
Jarque-Bera & 248.83 & 1.91 & 3.43 & 2.14 & 6.89 & 6.30 & 1.85 & 7.97 \\
Probability & 0.00 & 0.38 & 0.18 & 0.34 & 0.03 & 0.04 & 0.40 & 0.02 \\
Observations & 48 & 48 & 48 & 48 & 48 & 48 & 48 & 48 \\
\hline \hline
\end{tabular}

\section{Correlation Matrix}

The degree of the linear relation between the variables as measured by the correlation matrix is reported in Table 3. The table shows a largely positive direction of the relationship among the variables. For instance, except for lcar and laq all other variables return positive relationship with lcar. The high correlation between lcar and laq $(-0.678)$ should ordinarily signals the possibility of autocorrelation but the variables are both on the left-hand side of the equation and therefore do not feature in the same equation.

Table 3: Correlation Matrix

\begin{tabular}{lllllllll}
\hline \hline & Icar & laq & lry & Impr & lexr & Icpi & lasi & Ims \\
\hline \hline Icar & & -0.678 & 0.018 & 0.584 & 0.002 & 0.060 & 0.381 & 0.078 \\
Iaq & -0.678 & & -0.204 & -0.549 & 0.234 & -0.039 & -0.287 & 0.218 \\
Iry & 0.018 & -0.204 & & 0.662 & 0.749 & 0.913 & -0.212 & 0.577 \\
Impr & 0.584 & -0.549 & 0.662 & & 0.620 & 0.730 & 0.226 & 0.562 \\
lexr & 0.002 & 0.234 & 0.749 & 0.620 & & 0.919 & -0.138 & 0.870 \\
Icpi & 0.060 & -0.039 & 0.913 & 0.730 & 0.919 & & -0.124 & 0.767 \\
Iasi & 0.381 & -0.287 & -0.212 & 0.226 & -0.138 & -0.124 & & 0.031 \\
Ims & 0.078 & 0.218 & 0.577 & 0.562 & 0.870 & 0.767 & 0.031 & \\
\hline \hline
\end{tabular}

\section{Unit Root Test}

The study adopted Augmented Dickey-Fuller (ADF) based on the Akaike Information Criterion (AIC) and Phillips-Perron (PP) to determine the level of stationarity of the data used for the estimation. The result of the unit root test as presented in Table 4 indicates that all the variables are first differenced stationary I(1) based on both ADF and PP, except for lry and lasi which are reported I(0) based on PP and ADF, respectively. The absence of I(2) variables in the data further lends support to the use of ARDL methodology. 
Table 4: Unit Root Test

\begin{tabular}{|c|c|c|c|c|}
\hline \multirow{2}{*}{ Regressors } & \multicolumn{2}{|c|}{ ADF based on AIC } & \multicolumn{2}{|c|}{ Phillips-Perron } \\
\hline & $I(0)$ & $I(1)$ & $I(0)$ & $I(1)$ \\
\hline lcar & $-3.325785^{* *}$ & $-3.266832 * *$ & -2.536786 & $-6.320000 *$ \\
\hline laq & -1.776865 & $-3.225393 * *$ & -1.793272 & $-4.252721 *$ \\
\hline lry & -0.725561 & $-3.501778 * * *$ & $-4.258262 *$ & $-13.15673 *$ \\
\hline lcpi & -2.668114 & $-5.822322 *$ & -1.680148 & $-5.764901 *$ \\
\hline $\operatorname{lmpr}$ & 0.649052 & $-5.622983 *$ & 0.291271 & $-5.6995^{*}$ \\
\hline lexr & 0.072309 & $-5.743252 *$ & -0.038108 & $-5.677339 *$ \\
\hline lasi & $-3.620573 *$ & $-5.989391 *$ & -2.153931 & $-6.014736^{*}$ \\
\hline $\operatorname{lm} s$ & 1.189451 & $-6.940427^{*}$ & -1.195175 & $-21.01287^{*}$ \\
\hline
\end{tabular}

Note: *, ** and $* * *$ implies significant at 1.0, 5.0 and 10.0 per cent, respectively.

\section{Inferential Results}

\section{Cointegration Test}

The bounds test for both capital adequacy and asset quality equations are presented in Table 5 . From the table, the calculated F-statistics of 9.836045 and 8.079246 for capital adequacy and asset quality equations were respectively higher than the upper bounds of 4.43 for k equals 6 as tabulated in Pesaran, Shin and Smith (2001). Similarly, the t-statistics, as reported in the lower quadrant of the table, further corroborates the long-run relationships as the values of 7.948389 and -5.359588 are higher, in absolute term, than the -4.99 upper critical bound under 1.0 percent level of significance. These strongly prove the existence of a long-run relationship among the examined variables.

Table 5: Bounds Tests

\begin{tabular}{ccc|ccc}
\hline \hline \multicolumn{7}{c}{ Capital Adequacy } & \multicolumn{3}{c}{ Asset Quality } \\
\hline \hline Test Statistic & Value & $\mathrm{k}$ & Test Statistic & Value & $\mathrm{k}$ \\
\hline F-statistic & 9.836045 & 6 & F-statistic & 8.079246 & 6 \\
\hline \multicolumn{7}{c}{ Critical Value Bounds } \\
\hline Significance & $\mathrm{I}(0)$ Bound & $\mathrm{I}(1)$ Bound & Significance & $\mathrm{I}(0)$ Bound & $\mathrm{I}(1)$ Bound \\
\hline $10.00 \%$ & 2.12 & 3.23 & $10.00 \%$ & 2.12 & 3.23 \\
$5.00 \%$ & 2.45 & 3.61 & $5.00 \%$ & 2.45 & 3.61 \\
$2.50 \%$ & 2.75 & 3.99 & $2.50 \%$ & 2.75 & 3.99 \\
$1.00 \%$ & 3.15 & 4.43 & $1.00 \%$ & 3.15 & 4.43 \\
\hline \hline \multicolumn{7}{c}{ t-Bounds Test } & & 6 \\
\hline \hline t-statistic & -7.948389 & 6 & F-statistic & -5.359588 & \\
\hline \multicolumn{7}{c}{6} & Critical Value Bounds & & \\
\hline \hline Significance & $\mathrm{I}(0)$ Bound & $\mathrm{I}(1)$ Bound & Significance & $\mathrm{I}(0)$ Bound & $\mathrm{I}(1)$ Bound \\
\hline $10.00 \%$ & -2.57 & -4.04 & $10.00 \%$ & -2.57 & -4.04 \\
$5.00 \%$ & -2.86 & -3.13 & $5.00 \%$ & -2.86 & -4.38 \\
$2.50 \%$ & -3.43 & -4.66 & $2.50 \%$ & -3.13 & -4.66 \\
$1.00 \%$ & -4.99 & $1.00 \%$ & -3.43 & -4.99 \\
\hline \hline
\end{tabular}

\section{Long and Short-Run Results}

Table 6 shows the estimated long-run coefficients of the determinants of both capital adequacy ratio and asset quality models. The adjusted $\mathrm{R}^{2}$ of 0.90 and 0.99 for both equations indicate that the models are well-fitted. The long-run coefficients for capital adequacy equation (car), as 
depicted in the upper part of Table 6, return inflation (cpi), the anchor rate (mpr), the level of activities in the stock market (asi) and the oligopolistic structure of the banking industry ( $m s$ ) as determinants of capital adequacy of the Nigerian banking sector. While inflation and the oligopolistic structure of the industry is negatively related to risk-based capital adequacy, monetary policy rate and all share index is positively related to capital adequacy. The result seems to be theoretically coherent and in line with conventional wisdom. For instance, the risk appetite of banks tends to be on the increase in period of economic boom, arising from the creditworthiness of borrowers. Excessive lending by banks, in response to the borrower's creditworthiness, consequently erodes their capital base, hence as economic activities improves, the penchant for credit creation by banks rises and the level of capital falls. This largely corroborates the view of Andrian, He, Liang and Natalucci (2019) who contends that cyclical financial stability risks increases as the risk appetite of both lenders and borrowers rise due to accommodative financial conditions. This in-turn increases vulnerabilities in the financial system, arising from high borrowing and/or maturity mismatch. Rising vulnerabilities trigger shocks resulting in restrictive financial conditions that consequently affect economic growth. They are of the view that this process is mutually reinforcing.

Inflation is generally believed to be detrimental to banks' soundness. As the purchasing power of money falls due to a rise in the general price level, credit demand increases ${ }^{7}$, and this, in turn, leads to depletion in capital. Moreso, there is the probability of increase in default such that existing borrower's finds it difficult to service their loans, arising from erosion in the value of assets, hence increase in non-performing loan and consequently fall in car.

The positive coefficient of exchange rate, although not significant, connotes the fact that trading exchange gains serves as a veritable source of alternative income to banks. As the Naira/Dollar exchange rate depreciates, banks' appetite for credit creation moderates and foreign exchange trading increases. The trading exchange gains provides a veritable substitute with minimal risk and quick returns to banks thereby discouraging them from further intermediation, which unfreezes the capital base.

The anchor rate yields a positive coefficient vis-a-vis the capital adequacy ratio and statistically significant, implying that an increase in $m p r$ enhances the capital base of banks. An increase in mpr signals a rise in the cost of funds, which in turn leads to a fall in the demand for funds, thereby resulting in the accumulation of idle funds in banks.

${ }^{7}$ Not necessarily the number of credit. 
Table 6: Long-Run Coefficients

\begin{tabular}{|c|c|c|c|c|}
\hline \multicolumn{5}{|c|}{ Capital Adequacy Equation } \\
\hline Variable & Coefficient & Std. Error & t-Statistic & Prob. \\
\hline$r y$ & -0.188 & 1.113 & -0.169 & 0.868 \\
\hline cpi & -2.058 & 0.777 & -2.649 & 0.017 \\
\hline$m p r$ & 3.210 & 0.289 & 11.112 & 0.000 \\
\hline exr & 0.653 & 0.528 & 1.236 & 0.233 \\
\hline asi & 0.547 & 0.220 & 2.489 & 0.024 \\
\hline$m s$ & -0.483 & 5.283 & -0.091 & 0.928 \\
\hline \multicolumn{5}{|c|}{$R^{2}=0.96$, Adjusted $-R^{2}=0.90$} \\
\hline \multicolumn{5}{|c|}{$\begin{array}{cc}\text { Asset Quality Equation } \\
\end{array}$} \\
\hline$r y$ & -1.830 & 0.561 & -3.262 & 0.005 \\
\hline cpi & -0.033 & 0.499 & -0.066 & 0.948 \\
\hline exr & 2.419 & 0.333 & 7.273 & 0.000 \\
\hline mpr & -2.360 & 0.117 & -20.203 & 0.000 \\
\hline asi & 0.001 & 0.051 & 0.024 & 0.981 \\
\hline$m s$ & 0.585 & 3.105 & 0.188 & 0.853 \\
\hline \multicolumn{5}{|c|}{$R^{2}=0.996$, Adjusted $-R^{2}=0.990$} \\
\hline
\end{tabular}

The statistically significant positive coefficient of all share index (asi) implies that bullish trend in the capital market provides a viable alternative source of investment spending, probably due to increase in capital inflow, which in turn reduces loan demand pressure on banks, thereby lead to idle capital and consequently rise in the numerator (regulatory capital) and fall in the denominator - the risk-weighted assets (RWA).

In the case of asset quality equation reported in the lower part of Table 6, the level of economic activities, exchange rate, and the anchor rate are returned as major determinants. The level of economic activities and monetary policy rate recorded negative coefficients while the exchange rate returns a direct relationship with asset quality.

The level of economic activities, unlike in the case of capital adequacy, adversely affects the quality of assets of banks. It is evident from most financial crisis that bursts are always preceded by an economic boom. As the economy booms, the risk appetite of banks rises leading to excessive credit creation, part of which becomes non-performing at the peak of the boom. 
Table 7: Short-Run Dynamics

\begin{tabular}{|c|c|c|c|c|c|c|c|c|}
\hline & \multicolumn{4}{|c|}{ Capital Adequacy Equation } & \multicolumn{4}{|c|}{ Asset Quality Equation } \\
\hline & \multicolumn{4}{|c|}{ ARDL $(4,4,4,3,0,4,0)$} & \multicolumn{4}{|c|}{ ARDL $(4,4,4,4,3,0,2)$} \\
\hline Variables & Coefficient & Std. Error & t-Statistic & Prob. & Coefficient & Std. Error & t-Statistic & Prob. \\
\hline$c$ & 2.132 & 0.422 & 5.056 & 0.000 & 17.841 & 1.976 & 9.028 & 0.000 \\
\hline $\operatorname{Alcar}(-1)$ & 0.504 & 0.110 & 4.580 & 0.000 & & & & \\
\hline Alcar(-2) & 0.251 & 0.100 & 2.515 & 0.022 & & & & \\
\hline Alcar(-3) & 0.255 & 0.108 & 2.366 & 0.030 & & & & \\
\hline $\operatorname{Alaq}(-1)$ & & & & & 0.722 & 0.102 & 7.050 & 0.000 \\
\hline $\operatorname{slaq}(-2)$ & & & & & 0.174 & 0.082 & 2.105 & 0.053 \\
\hline $\operatorname{slaq}(-3)$ & & & & & 0.353 & 0.054 & 6.523 & 0.000 \\
\hline Alry & -23.244 & 4.209 & -5.523 & 0.000 & 1.942 & 0.807 & 2.407 & 0.029 \\
\hline $\operatorname{Alry}(-1)$ & -20.892 & 4.136 & -5.051 & 0.000 & 4.427 & 0.926 & 4.780 & 0.000 \\
\hline $\operatorname{slry}(-2)$ & -21.527 & 4.227 & -5.093 & 0.000 & 3.565 & 0.948 & 3.760 & 0.002 \\
\hline $\operatorname{Alry}(-3)$ & -22.574 & 4.211 & -5.361 & 0.000 & 3.360 & 0.805 & 4.177 & 0.001 \\
\hline$\Delta l c p i$ & -13.248 & 3.684 & -3.596 & 0.002 & 9.007 & 1.121 & 8.034 & 0.000 \\
\hline Alcpi(-1) & -4.123 & 3.390 & -1.216 & 0.241 & 5.246 & 1.296 & 4.046 & 0.001 \\
\hline Alcpi(-2) & -9.559 & 3.257 & -2.935 & 0.009 & 8.410 & 1.170 & 7.185 & 0.000 \\
\hline Alcpi(-3) & -12.644 & 3.664 & -3.451 & 0.003 & 3.057 & 1.141 & 2.680 & 0.017 \\
\hline$\Delta l m p r$ & 0.736 & 0.608 & 1.211 & 0.242 & -0.537 & 0.152 & -3.533 & 0.003 \\
\hline$\Delta \operatorname{lmpr}(-1)$ & -4.115 & 0.816 & -5.043 & 0.000 & 1.508 & 0.417 & 3.618 & 0.003 \\
\hline$\Delta \operatorname{lmpr}(-2)$ & -3.081 & 0.705 & -4.369 & 0.000 & 1.015 & 0.233 & 4.362 & 0.001 \\
\hline Alasi & 0.387 & 0.301 & 1.288 & 0.215 & & & & \\
\hline Alasi(-1) & -1.116 & 0.352 & -3.172 & 0.006 & & & & \\
\hline Alasi(-2) & -1.360 & 0.312 & -4.357 & 0.000 & & & & \\
\hline Alasi(-3) & -1.088 & 0.412 & -2.640 & 0.017 & & & & \\
\hline Alexr & & & & & 1.564 & 0.178 & 8.805 & 0.000 \\
\hline Alexr(-1) & & & & & -1.810 & 0.316 & -5.729 & 0.000 \\
\hline$\Delta \operatorname{lexr}(-2)$ & & & & & -0.355 & 0.237 & -1.499 & 0.155 \\
\hline $4 \operatorname{lexr}(-3)$ & & & & & -1.191 & 0.211 & -5.635 & 0.000 \\
\hline$\Delta l m s$ & & & & & -3.089 & 1.589 & -1.944 & 0.071 \\
\hline $\operatorname{Alms}(-1)$ & & & & & -6.122 & 1.736 & -3.527 & 0.003 \\
\hline \multirow[t]{2}{*}{$\operatorname{ecm}(-1)$} & -1.848 & 0.192 & -9.652 & 0.000 & -1.767 & 0.199 & -8.898 & 0.000 \\
\hline & \multicolumn{4}{|c|}{$\begin{array}{c}R^{2}=0.906, \text { Adjusted }-R^{2}=0.824 ; \text { AIC }= \\
0.315924 ; S B C=1.167469 ; H Q C=0.631718 ; \\
D W=2.346\end{array}$} & \multicolumn{4}{|c|}{$\begin{array}{c}R^{2}=0.974, \text { Adjusted }-R^{2}=0.947 ; \text { AIC }=- \\
2.492390 ; S B C=-1.559745 ; H Q C=-2.146520 ; \\
D W=2.813\end{array}$} \\
\hline
\end{tabular}

Note: AIC = Akaike Information Criterion, SBC Schwarz Bayesian Criterion, HQC = Hannan Quinn Criterionand, $D W=$ Durbin Watson Statistics

The value of the Naira vis-à-vis the US dollar seems to be critical in determining the quality of assets of Nigerian banks during the study period. As the value of domestic currency depreciates, so do the value of the assets (at least book value) created by the banks appreciate. The higher the anchor rate, the lower the quality of assets of banks. As MPR rises, short-term interest rates follow suit which makes outstanding credits highly unserviceable leading to an increase in the rate of defaults.

Table 7 displays the short-run dynamics of the models. The table shows the ability to return to equilibrium in case of distortions in the economy. The error correction coefficients of both equations are negatively signed and statistically significant. This implies the feasibility of restoration of equilibrium in case of distortions in the economy. It further affirms cointegration among the variables of interest as revealed in the bounds test. 
The ecm of the capital adequacy equation is 184.8 percent. This indicates that disequilibrium can be corrected in less than one quarter. Similarly, with 176.7 percent coefficient of ecm for quality equation, it takes the economy far less than a quarter to re-establish equilibrium in case of distortions. Thus, restoration of equilibrium in both cases is very fast.

\section{Diagnostic Tests}

To test the stability of the estimated equations and parameters, cumulative sum (CUSUM) and cumulative sum of squares (CUSUMSQ) test were carried out. As reported in Figures 1 to 4, both models and estimated parameters were stable throughout the study period, as the movement lies within 5.0 percent critical bounds.

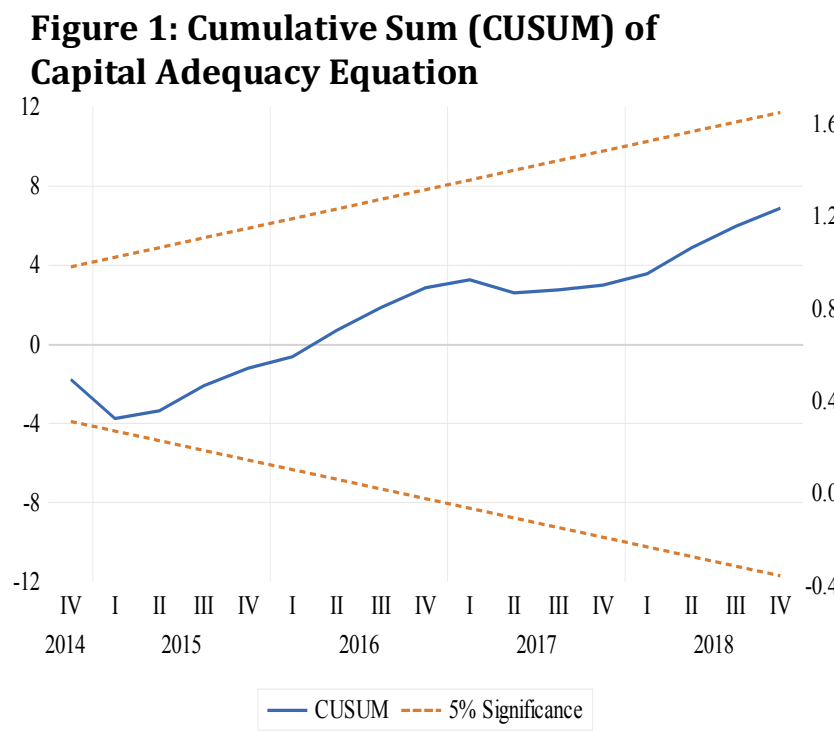

Figure 3: Cumulative Sum (CUSUM) of Asset Quality Equation

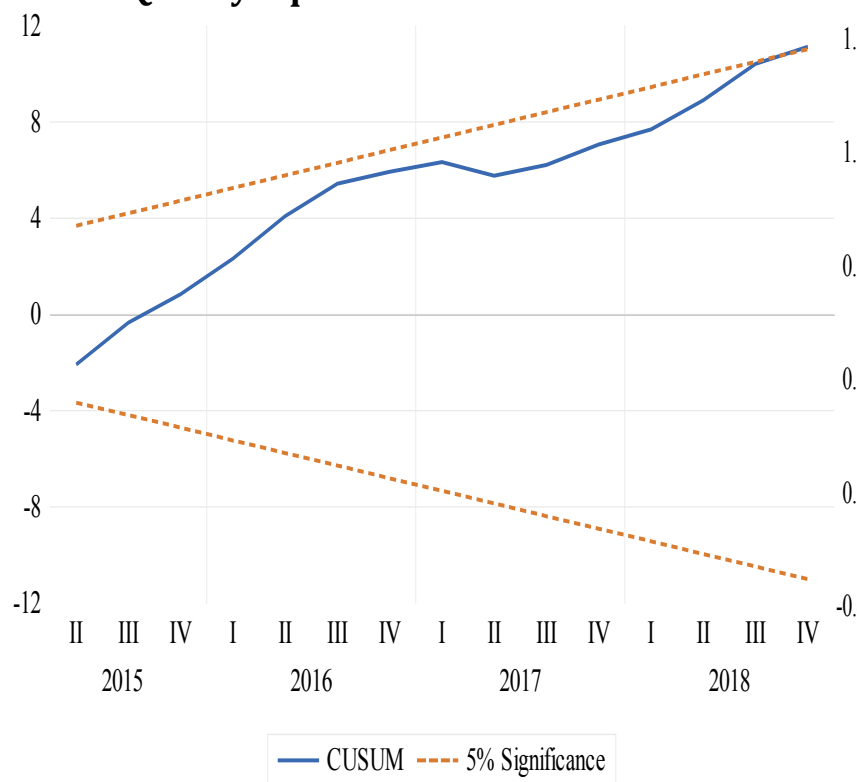

Figure 2: Cumulative Sum of Squares (CUSUMSQ) of Capital Adequacy Equation

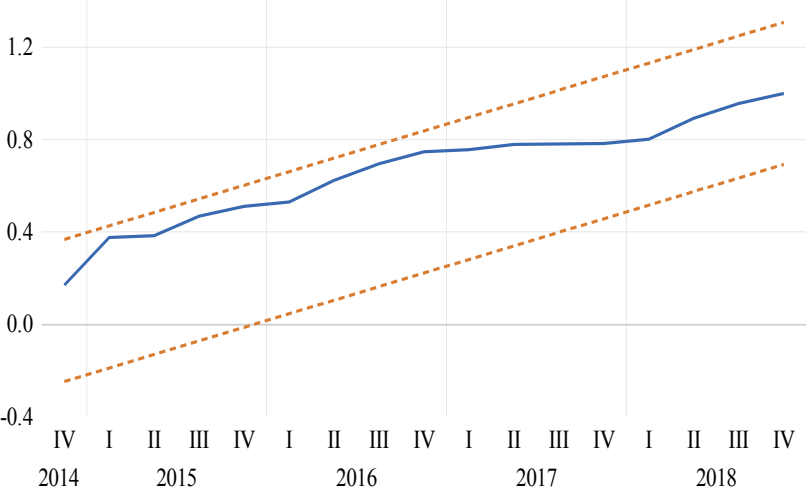

— CUSUM of Squares ---- 5\% Significance
Figure 4: Cumulative Sum of Squares (CUSUMSQ) of Asset Quality Equation

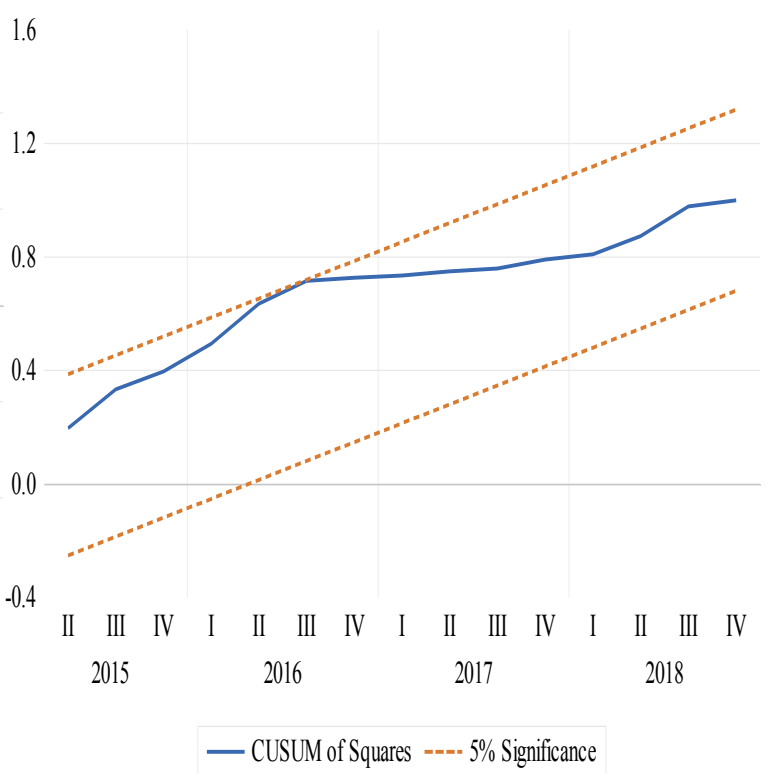

CONCLUSION AND POLICY RECOMMENDATION

The growing concern amongst analysts, economists, and policymakers on the interrelationship between the soundness of the financial system and the macro-economy is gradually being confirmed by both theoretical and empirical studies. This study has succeeded in joining the strand of literature that investigates the link between the soundness of the banking sector and macroeconomic performance using Nigeria quarterly data from 2007Q1 to 2018Q4. 
The results largely corroborate the findings of Yaaba (2016) which showed that FSIs are strongly related to the macroeconomic variables hence capable of pre-empting financial crisis in Nigeria. While robust economic growth is required to enhance activities in the financial sector, it seems to prepare ground for the erosion of banks' capital, which consequently leads to poor quality of banks' assets. There is a need for close supervision/monitoring of banks during an economic boom. This is to check the possibility of excessive appetite for risk by banks that is capable of igniting crisis at the turn of events. Inflation erodes the bank capital and therefore frantic policy effort should be made to reduce inflationary spiral. More so, both onsite and offsite supervision and monitoring of banks should be strengthened at times of high inflation to enable early detection of scenarios that can flare up crisis in the banking system.

The effect of the CBN anchor rate on banks seems to require scrutiny through frequent and continuous research. Banks seem to have the habit of transmitting not only the cost of inflation to the end-users of capital but also any upward review in the anchor rate (i.e. MPR). Upward adjustment in the policy rate seems to moderately serve the purpose of keeping regulatory capital fairly in line with the policy objective of the CBN, but exerts significant pressure on the quality of assets of the banks. The existence of sound and strong banks, however, goes beyond robust capital adequacy level to the ability of banks to improve the quality of their loan portfolio and credit administration program. An increase in nonperforming loans relative to total loans is undoubtedly one of the fundamental causes of the banking sector crisis across the globe. We therefore, advocate for the CBN to roll out policies that could check the expansion of NPL to avoid bank liquidation. The Bank should also thread cautiously in managing credit creation because the increase in NPLs and reduction in credit creation may collectively suppress already improving economic growth leading to another downward spiral.

Finally, there is the need for collaboration between the CBN and Securities and Exchange Commission in monitoring the stock market. Bullish and bearish trends in the stock market serve as a signal to happenings in the banking sector. Therefore, effective monetary and macroprudential regulations should be designed to moderate any negative effect of the activities in the stock market that can have bearing on the performance of the banking system.

\section{References}

Abubakar, M. \& Yaaba, B.N. (2013). A Post Market Reform Analysis of Monetary Conditions Index for Nigeria. Journal of Economics and Sustainable Development, 4(14), pp.1-11.

Albulescu, C. T. (2014). Banks' Profitability and Financial Soundness Indicators: A Macro-Level Investigation in Emerging Countries. Procedia Economics and Finance 23, 203 - 209.

Adrian, T., He, D., Liang, N. and Natalucci, F. (2019). Monitoring Global Financial Stability, available at https://blogs.imf.org/2019/08/26/monitoring-global-financial-stability/

Babihuga, R. (2007). “Macroeconomic and Financial Soundness Indicators: An Empirical Investigation”, IMF Working Paper No. 2007/115.

Claessens, S. \& Kodres, L. (2014). The Regulatory Responses to the Global Financial Crisis: Some Uncomfortable Questions. International Monetary Fund, Working Paper, WP/14/46.

Creel, J., Hubert, P., \& Labondance, F. (2015). Financial stability and Economic Performance. Economic Modelling, $48,25-40$.

Demirgüç-Kunt, A., and Detragiache E. (1998). The Determinants of Banking Crises in Developing and Developed Countries. Staff Papers, International Monetary Fund, Vol. 45, No. 1, pp. 81-109.

Das, U. S., Quintyn, M. \& Chenard, K. (2004). Does Regulatory Governance Matter for Financial System Stability? An Empirical Analysis. IMF Working Paper No. 04/89.

Dhal, S., Kumar, P., \& Ansari, J. (2011). Financial Stability, Economic Growth, Inflation and Monetary Policy Linkages in India: An Empirical Reflection. Reserve Bank of India Occasional Papers, 32(3), 1-35. 
Harris, R. and R. Sollis (2003). Applied Time Series Modelling and Forecasting. West Essex Wiley. International Monetary Fund (2006): Financial Soundness Indicators: Compilation Guide, March.

Jahn, N. \& Kick, T. (2012). Determinants of Banking System Stability: A Macro-Prudential Analysis. BIS Working Paper.

Pesaran, M. H., Shin, Y. \& Smith, R. J. (2001). Bound Testing Approaches to the Analysis of Level Relationship. Journal of Applied Econometrics. John Willey and Sons Ltd

Morley, J. (2015). Macro-Finance Linkages, Journal of Economic Surveys, 30(4), 698-711.

Petria, N., Capraru, B., \& Ihnatov, I. (2015). Determinants of Banks' Profitability: Evidence from EU 27 Banking Systems. Procedia Economics and Finance, 20, 518-524.

Sere-Ejembi, A., Udom, I. S., Audu, S., Atoi, N. V. and Yaaba, B. N. (2014). Developing a Banking System Stability Index for Nigeria. CBN Journal of Statistics, 5(1), pp $49-77$.

Shahbaz, M., Aamir Shamim, S. M. \& Aamir, N. (2010). Macroeconomic Environment and Financial Sector's Performance: Econometric Evidence from three Traditional Approaches. The IUP Journal of Financial Economics, VIII (1 \& 2), pp 103-123.

Yaaba B. N. (2011). "Financial Soundness Indicators: Can we use them to avert Banking Crisis? Nigerian Journal of Economic and Social Sciences (NJESS), 54(1), pp 69-91.

Yaaba, B. N. (2013). Monetary Policy Rule: A Broad Monetary Conditions Index for Nigeria. CBN Journal of Applied Statistics, 4(1), pp 35-53.

Yaaba B. N. \& Adamu, I. (2015). Financial Soundness Indicators: The Case of Nigeria, The CBN Bullion. 39(4), pp. 314.

Yaaba B. N. (2016). Financial Soundness Indicators and Macroeconomic Variables: An Empirical Investigation of the Dynamic Linkages. The CBN Bullion, 40(1), pp 9-20. 